\title{
Comparative Study of Mustard Oil Cake and Soybean Meal Based Artificial Diet for Rohu, Labeo rohita (Ham.) Fingerlings
}

\author{
D. A. Jahan ${ }^{1 *}$, L. Hussain ${ }^{2}$, M. A. Islam² and M. Khan ${ }^{1}$ \\ ${ }^{1}$ Bangladesh Fisheries Research Institute (BFRI), Freshwater Station, Mymensingh-2201 \\ ${ }^{2}$ Dept. of Fisheries Biology and Genetics, Bangladesh Agricultural University, Mymensingh-2202 \\ *Corresponding author and Email: durin_bfri@yahoo.com
}

Received: 12 August $2012 \quad$ Accepted: 18 May 2013

\begin{abstract}
An experiment was conducted to evaluate the nutritive potential of soybean meal and mustard oil cake based diets for rearing of Labeo rohita fingerlings under pond condition at the Bangladesh Agricultural University, Mymonsingh during 2008. Three diets designated as treatments were formulated and fed to the stocked fingerlings. Studies have revealed an increase in final weight, average live weight gain, specific growth rate (SGR), lower food conversion ratio (FCR), protein efficacy ratio (PER) and apparent net protein utilization (ANPU\%) and survival of fingerlings fed on diet $\mathrm{D}_{3}$, a soybean meal based diet. Carcass composition also revealed high protein and lipid in fish fed on the diet $\mathrm{D}_{3}$.
\end{abstract}

\section{Keywords: Mustard oil cake, soybean meal, Labeo rohita}

\section{Introduction}

Supplementary feeding is an important tool for augmenting fish production and optimization of fish production requires research on feeding techniques. In fish diet, protein is an important ingredient for its influence on growth and diet cost.

Fishmeal has traditionally been used as a major protein source in feeds for semi intensive and intensive fish farming because of its high nutritive value and palatability. However, fishmeal is expensive and is difficult to be obtained in many countries. So, its high demand has resulted in price increase, making it a burden for fish farmers. Dependency on fishmeal is a severe constraint to fish farming in Bangladesh. High cost and short supply of fishmeal have necessitated its substitution with cheaper plant protein sources. In recent years, plant proteins are being extensively used in fish and prawn feeds, mainly to replace the fishmeal component, in order to reduce the feed cost (Priyadarshini et al., 2011).

The amount of plant protein used in fish diet depends on the species, availability, cost and acceptability by fish, presence of nutrient and antinutritional factors (Lim and Dominy, 1990). Singh et al. (2005) opined that optimum protein requirements vary with the protein sources and feed ingredients that are locally available and cheap protein sources should be used to develop a suitable feed for carp. In Bangladesh, most promising alternatives to fishmeal in carp diets are oilseed meal i.e. mustard oil cake, linseed meals and sesame meal (Hossain and Jauncey, 1989). Besides, soybean meals is considered to be the most nutritive plant protein and are used as the major protein source in diets (El-Sayed, 1999). Devi et al. (1999) observed that rohu fingerlings can accept up to $60 \%$ soybean meal based diet which is exhibited through their 
growth. An attempt was therefore, made to address the nutritive potential of soybean meal based diets compared to mustard oil cake based diets on the growth of $L$. rohita fingerlings.

\section{Materials and Methods}

\subsection{Experimental design}

The experiment was conducted in 9 earthen ponds for a period of 60 days in the Field Laboratory Complex of the Faculty of Fisheries, Bangladesh Agricultural University, Mymonsingh during 2008. The area of each pond was $60 \mathrm{~m}^{2}$. The experimental design was CRD. Three treatments each with three replications were designed to evaluate the nutritional potential of the formulated diets.

\subsection{Pond preparation}

The ponds were drained out completely and were then exposed to sunlight for three days; treated with lime at the rate of $250 \mathrm{~kg} \mathrm{ha}^{-1}$ and left for 3 days. Organic and inorganic fertilizers such as cowdung, urea and triple super phosphate were applied at the rate of 1000,25 and $25 \mathrm{~kg} \mathrm{ha}^{-1}$, respectively for pond fertilization as a basal dose. After the fingerling stocking, $50 \%$ of the basal dose was applied at every 15 days interval throughout the experimental period. After pond preparation the fishes $(2.80 \mathrm{~g} \pm 0.01)$ were stocked at a density of 75,000 ha- ${ }^{-1}$.

\subsection{Experimental diets}

The conventional mixture of mustard oil cake and rice bran in equal proportion (50:50) was used as the control diet $\left(D_{1}\right)$ whereas diet $D_{2}$ consisted of mustard oil cake, soybean meal and rice bran $(25: 25: 50)$ and diet $\mathrm{D}_{3}$ consisted of soybean meal and rice bran (50:50). Prior to prepare pellet feed, all the ingredients were finely powdered, mixed and then sieved. Proximate compositions of the ingredients used in the formulated diets are presented in Table 1 and the experimental diets in Table 2. Fishes were fed at the rate of $3 \%$ of their body weight for initial 5 days, followed by $5 \%$ in the subsequent days of the culture period. Feeding was done by broadcasting the mixture in two installments, $50 \%$ in the morning (7-8 am) and the rest $50 \%$ in the afternoon (3-4 pm).

\subsection{Water sampling and analysis}

The water quality parameters such as temperature $\left({ }^{\circ} \mathrm{C}\right)$, secchi depth $(\mathrm{cm}), \mathrm{pH}$, dissolved oxygen $\left(\mathrm{mgL}^{1}\right)$, ammonia $\left(\mathrm{mgL}^{-1}\right)$ and total hardness $\left(\mathrm{mgL}^{-1}\right)$ were analyzed at seven days interval according to standard method (APHA, 1990). Quantitive and qualitative abundance of phyto and zooplankton were analyzed according to Bellinger (1992) at an interval of 15 days by filtering of $50 \mathrm{~L}$ of water through silk netting (mesh size $64 \mu$ ).

\subsection{Analytical methods and analysis of data}

Proximate composition of diet ingredients, diets and whole body were analyzed following AOAC (1990) methods. Specific growth rate (SGR), \% weight gain, food conversion ratio (FCR), protein efficiency ratio (PER) and apparent net protein utilization (ANPU\%) were calculated as follows:

SGR $(\% /$ day $)=[($ Ln. Final body weight Ln. Initial body weight) / days $\times 100]$

$\%$ Weight gain $=($ Final body weight - Initial body weight / Initial body weight $) \times 100$

FCR $=$ Food fed $(\mathrm{g}$ dry weight $) /$ Live weight gain $(\mathrm{g})$

PER = Live weight gain $(\mathrm{g}) /$ Crude protein fed (g dry weight)

ANPU $(\%)=($ Net increase in carcass protein/Protein consumed) $\times 100$

All data collected were subjected to one-way analysis of variance (ANOVA) followed by Duncan's multiple range tests (Duncan, 1955) to test the difference between means. Standard deviation $( \pm \mathrm{SD})$ was calculated to identify the range of means. 
Table 1. Proximate composition of the feed ingredients used in different diets ( $\%$ on dry matter basis)

\begin{tabular}{lllllll}
\hline Ingredients & $\begin{array}{l}\text { Dry } \\
\text { matter }\end{array}$ & $\begin{array}{l}\text { Crude } \\
\text { protein }\end{array}$ & $\begin{array}{l}\text { Crude } \\
\text { lipid }\end{array}$ & Ash & $\begin{array}{l}\text { Crude } \\
\text { fiber }\end{array}$ & NFE $^{\mathbf{1}}$ \\
\hline Soybean meal & 91.52 & 43.30 & 15.55 & 5.71 & 4.95 & 30.49 \\
Mustard oil cake & 86.31 & 28.50 & 14.87 & 10.40 & 12.21 & 34.02 \\
Rice bran & 90.44 & 12.40 & 8.82 & 10.48 & 16.34 & 51.96 \\
\hline
\end{tabular}

${ }^{1}$ Nitrogen Free Extract

Table 2. Ingredient (\%) and proximate composition of the different diets (\% on dry matter basis)

\begin{tabular}{llll}
\hline & \multicolumn{3}{c}{ Diets/Treatments } \\
\cline { 2 - 4 } Ingredients $\left(\mathbf{g ~} \mathbf{1 0 0} \mathbf{g}^{-\mathbf{1}}\right)$ & $\mathbf{D}_{\mathbf{1}}$ & $\mathbf{D}_{\mathbf{2}}$ & $\mathbf{D}_{\mathbf{3}}$ \\
\hline Rice bran & 50 & 50 & 50 \\
Mustard oil cake & 50 & 25 & 0 \\
Soybean meal & 0 & 25 & 50 \\
Proximate composition & & & \\
Crude protein & $22.38^{\mathrm{c}} \pm 0.23$ & $26.32^{\mathrm{b}} \pm 0.15$ & $28.05^{\mathrm{a}} \pm 0.26$ \\
Crude lipid & $12.35^{\mathrm{a}} \pm 0.26$ & $11.79^{\mathrm{a}} \pm 0.16$ & $12.27^{\mathrm{a}} \pm 0.27$ \\
Ash & $09.33^{\mathrm{b}} \pm 0.23$ & $10.42^{\mathrm{a}} \pm 0.14$ & $07.63^{\mathrm{c}} \pm 0.18$ \\
Crude fibre & $15.65^{\mathrm{a}} \pm 0.06$ & $11.53^{\mathrm{b}} \pm 0.29$ & $12.36^{\mathrm{b}} \pm 0.36$ \\
NFE & $40.29^{\mathrm{a}} \pm 0.74$ & $39.94^{\mathrm{a}} \pm 0.20$ & $39.69^{\mathrm{a}} \pm 01.0$ \\
Gross energy $^{2}$ & 16.78 & 15.41 & 17.62 \\
PE ratio $^{3}$ & 13.34 & 17.07 & 15.62 \\
\hline
\end{tabular}

*Values having the same subscripts in the same row are not significantly different $(\mathrm{P}>0.05)$

${ }^{1} \mathrm{NFE}=$ Nitrogen free extractives, calculated as $100-(\%$ protein $+\%$ Lipid $+\%$ Ash $+\%$ Fibre $)$

${ }^{2} \mathrm{GE}=$ Gross energy content

${ }^{3} \mathrm{P} / \mathrm{GE}$ ratio $=$ Protein to energy ratio in $\mathrm{mg}$ protein $\mathrm{kJ}^{-1} \mathrm{GE}$

\section{Results and Discussion}

During the experimental period, mean physiochemical qualities of water as obtained from the different experimental ponds are presented in Table 3. Mean water quality parameters of the experimental ponds were in the following ranges: temperature 29.60 to $30.11^{\circ} \mathrm{C}$, dissolved oxygen 4.90 to $5.90 \mathrm{mgL}^{-1}$, alkalinity 172.15 to $184.94 \mathrm{mgL}^{-1}, \mathrm{pH} 7.53$ to 7.44 , secchi depth 27.66 to $36.41 \mathrm{~cm}$ and ammonia 0.21 to 0.26 $\mathrm{mgL}^{-1}$.

The quantitative analysis of phytoplankton and zooplankton showed average density of $30.90 \pm 7.74 \times 10^{3} \mathrm{~L}^{-1}$ and $37.64 \pm 8.53 \times 10^{3} \mathrm{~L}^{-1}$, $47.47 \pm 8.04 \times 10^{3} \mathrm{~L}^{-1}$ and $13.95 \pm 4.58 \times 10^{3} \mathrm{~L}^{-1}$,
$20.77 \pm 4.74 \times 10^{3} \mathrm{~L}^{-1}$ and $24.79 \pm 7.71 \times 10^{3} \mathrm{~L}^{-1}$ in diet/treatment 1,2 and 3, respectively (Table 4). Treatment to treatment variation was not statistically significant $(\mathrm{P}>0.05)$ in case of density of zooplankton but statistically significant difference $(\mathrm{P}>0.05)$ was observed in phytoplankton density. Among plankton samples, phytoplankton constituted 68.01, 64.97, $67.8 \%$ while zooplankton constituted 30.07, $35.56,31.10 \%$ of total population. Suitable water quality is a prerequisite for the maintenance of healthy aquatic environmental condition of the pond water. In the present study better planktonic population and optimum productivity were obtained through the application of fertilizer in ponds which agree with the report of Jhingran \& Pullin (1985). It may be said that the 
fertilizer might have enriched water quality to optimize planktonic population for carp culture.

In the present study, experimental diets were formulated to a protein level of $22-28 \%$ which was a fairly balance diet for better growth of fishes. Protein levels in successful feeds range from $20-60 \%$ to accommodate for differences in the physiological needs of different fish species (Hepher, 1988; Wilson, 1989). Singh et al. (2005) conducted an experiment to determine the effect of varying protein levels $(25-40 \%)$ on $L$. rohita growth and digestibility. In the present study, the experimental diet $\mathrm{D}_{3}$ gave significantly better growth in comparison with $\mathrm{D}_{1}$ and $\mathrm{D}_{2}$. Final weight gain and SGR increased with inclusion of soybean meal in the diets. Rohu achieved the maximum average weight of 14.18 $\mathrm{g}$ with diet $\mathrm{D}_{3}$ against $7.72 \mathrm{~g}$ with control diet $\mathrm{D}_{1}$ (Table 5). There were no statistical difference $(\mathrm{P}>0.05)$ between the treatment in respect of survival rate.

Protein content in the diet has significantly affected the growth of carp fingerlings. Better growth performance in fishes fed on diet $D_{3}$ could also be due to better feed management. Latif et al. (2008) reported that mustard oil cake, soybean meal, seasame meal, linseed meal (25:25:25:25) fed L. rohita showed poor growth performance in comparison with the diet consisted of soybean meal, seasame meal, linseed meal (40:30:30). Singh and Dhawan (1996) obtained almost similar result in $C$. carpio.
In the present study, a decreasing trend in the FCR value with the increase in the proportion of soybean meal in diet was obtained and diet $\mathrm{D}_{3}$ was found to be significantly better $(\mathrm{P}<0.05)$ than the other two diets (Table 5). Increased PER $(1.85 \pm 0.02)$ value was obtained with diet $\mathrm{D}_{3}$ while the minimum $(1.59 \pm 0.80)$ with diet $\mathrm{D}_{1}$ and there was no statistical difference $(\mathrm{P}<0.05)$ between the results of $D_{2}$ and $D_{3}$ but both showed significant difference from diet $\mathrm{D}_{1}$. The effects on FCR and PER indicate that diet $\mathrm{D}_{3}$ was better for rearing of rohu fingerlings. While Hossain and Jauncey (1989) attributed poor growth response of $C$. carpio fed on diets containing mustard oil cake. Moreover, Devi et al. (1999) observed higher feed protein efficacy in the diet of rohu having soybean meal and also obtained higher protein level in the tissues of rohu.

Results obtained on the carcass composition of fish belonging to different treatments are presented in Table 6 . The crude protein value of fish fed with diet $\mathrm{D}_{3}$ was $16.39 \pm 0.11 \%$ compared to $14.33 \pm 0.32 \%$ with control diet $\mathrm{D}_{1}$ and corresponding crude lipid values were $4.56 \pm$ 0.20 and $3.80 \pm 0.42 \%$, respectively. Increased lipid levels in diet $\mathrm{D}_{2}$ and $\mathrm{D}_{3}$ could be due to the converted carbohydrate which was not utilized to provide energy. Jena et al. (1999) advocated that crude protein and lipid levels were also higher in rohu tissues fed with soybean meal based diet than a conventional mixture of mustard oil cake and rice bran.

Table 3. Physico-chemical parameters (mean \pm SE) of ponds' water as recorded during the experimental period of 60 days

\begin{tabular}{llll}
\hline Parameters & \multicolumn{3}{c}{ Diets/Treatments } \\
\cline { 2 - 4 } & $\mathbf{D}_{\mathbf{1}}$ & $\mathbf{D}_{\mathbf{2}}$ & $\mathbf{D}_{\mathbf{3}}$ \\
\hline Temperature $\left({ }^{\circ} \mathrm{C}\right)$ & $29.60^{\mathrm{a}} \pm 0.19$ & $29.97^{\mathrm{a}} \pm 0.17$ & $30.11^{\mathrm{a}} \pm 0.13$ \\
Dissolved oxygen $\left(\mathrm{mgL}^{-1}\right)$ & $5.90^{\mathrm{a}} \pm 0.19$ & $4.96^{\mathrm{b}} \pm 0.10$ & $4.90^{\mathrm{b}} \pm 0.13$ \\
Total alkalinity $\left(\mathrm{mgL}^{-1}\right)$ & $180^{\mathrm{ab}} \pm 0.06$ & $172.15^{\mathrm{b}} \pm 4.84$ & $184.94^{\mathrm{a}} \pm 3.36$ \\
$\mathrm{pH}$ & $7.40^{\mathrm{a}} \pm 0.07$ & $7.44^{\mathrm{a}} \pm 0.091$ & $7.53^{\mathrm{a}} \pm 0.44$ \\
& $(6.73-7.90)$ & $(6.75-7.98)$ & $(6.77-8.23)$ \\
Transparency $(\mathrm{cm})$ & $36.41^{\mathrm{a}} \pm 2.31$ & $30.0^{\mathrm{b}} \pm 2.0$ & $27.66^{\mathrm{b}} \pm 1.92$ \\
$\mathrm{NH}^{3}-\mathrm{N}\left(\mathrm{mgL}^{-1}\right)$ & $0.21^{\mathrm{a}} \pm 0.02$ & $0.26^{\mathrm{a}} \pm 0.01$ & $0.22^{\mathrm{a}} \pm 0.02$ \\
\hline
\end{tabular}


Table 4. Major groups of Phytoplankton and Zooplankton as recorded from water of the experimental pond $\left(\times 10^{3} \mathrm{~L}^{-1}\right)$ during the study period

\begin{tabular}{llll}
\hline Plankton group & \multicolumn{3}{c}{ Diets/Treatments } \\
\cline { 2 - 4 } & $\mathbf{D}_{\mathbf{1}}$ & $\mathbf{D}_{\mathbf{2}}$ & $\mathbf{D}_{\mathbf{3}}$ \\
\hline Phytoplankton & & & \\
Bacillariophyceae & $4.85^{\mathrm{b}} \pm 1.08$ & $6.10^{\mathrm{ab}} \pm 3.29$ & $8.28^{\mathrm{a}} \pm 3.33$ \\
Chlorophyceae & $17.71^{\mathrm{a}} \pm 3.10$ & $20.10^{\mathrm{a}} \pm 7.22$ & $23.04^{\mathrm{a}} \pm 6.28$ \\
Cyanophyceae & $6.67^{\mathrm{b}} \pm 3.56$ & $9.11^{\mathrm{ab}} \pm 4.31$ & $11.75^{\mathrm{a}} \pm 3.88$ \\
Euglenophyceae & $1.67^{\mathrm{b}} \pm 0.57$ & $2.33^{\mathrm{b}} \pm 0.77$ & $4.90^{\mathrm{a}} \pm 2.80$ \\
Total & $\mathbf{3 0 . 9 0}^{\mathrm{b}} \pm \mathbf{7 . 7 4}$ & $\mathbf{3 7 . 6 4}^{\mathrm{ab}} \pm \mathbf{8 . 5 3}$ & $\mathbf{4 7 . 9 7}^{\mathrm{a}} \pm \mathbf{8 . 0 4}$ \\
Zooplankton & & & \\
Crustacea & & $14.89^{\mathrm{a}} \pm 6.57$ & $17.90^{\mathrm{a}} \pm 6.54$ \\
Rotifera & $9.53^{\mathrm{b}} \pm 5.11$ & $5.88^{\mathrm{a}} \pm 2.8$ & $6.89^{\mathrm{a}} \pm 2.02$ \\
Total & $4.42^{\mathrm{a}} \pm 2.23$ & $\mathbf{2 0 . 7 7} \pm \mathbf{4 . 7 4}$ & $\mathbf{2 4 . 7 9} \pm \mathbf{7 . 7 1}$ \\
Grand Total & $\mathbf{1 3 . 9 5} \pm \mathbf{4 . 5 8}$ & $\mathbf{5 8 . 4 1} \pm \mathbf{7 . 5 4}$ & $\mathbf{7 2 . 7 6} \pm \mathbf{7 . 8 8}$ \\
\hline
\end{tabular}

Table 5. Growth, food conversion ratio, survival rate and protein utilization of $L$. rohita fingerlings fed on different diets for 60 days (Mean \pm SD)

\begin{tabular}{llll}
\hline Parameters & \multicolumn{3}{c}{ Diets/Treatments } \\
\cline { 2 - 4 } & $\mathbf{D}_{\mathbf{1}}$ & $\mathbf{D}_{\mathbf{2}}$ & $\mathbf{D}_{\mathbf{3}}$ \\
\hline Average initial weight $(\mathrm{g})$ & $2.80 \pm 0.01$ & $2.80 \pm 0.01$ & $2.80 \pm 0.01$ \\
Average final weight $(\mathrm{g})$ & $7.72^{\mathrm{c}} \pm 0.29$ & $11.98^{\mathrm{b}} \pm 0.27$ & $14.18^{\mathrm{a}} \pm 0.35$ \\
Average live weight gain $(\%)$ & $175.50^{\mathrm{c}} \pm 8.94$ & $327.72^{\mathrm{b}} \pm 0.27$ & $406.27^{\mathrm{a}} \pm 8.60$ \\
SGR $(\%)$ & $8.20^{\mathrm{c}} \pm 0.46$ & $15.29^{\mathrm{b}} \pm 8.20$ & $18.96^{\mathrm{a}} \pm 0.55$ \\
PER & $1.59^{\mathrm{b}} \pm 0.80$ & $1.84^{\mathrm{a}} \pm 0.43$ & $1.85^{\mathrm{a}} \pm 0.02$ \\
FCR & $3.07^{\mathrm{a}} \pm 0.16$ & $2.26^{\mathrm{b}} \pm 0.02$ & $1.96^{\mathrm{c}} \pm 0.02$ \\
ANPU $(\%)$ & $25.19^{\mathrm{b}} \pm 0.50$ & $29.67^{\mathrm{a}} \pm 0.66$ & $32.43^{\mathrm{a}} \pm 1.93$ \\
Survival rate & $89^{\mathrm{a}} \pm 3.06$ & $92^{\mathrm{a}} \pm 2.00$ & $90^{\mathrm{a}} \pm 2.00$ \\
\hline
\end{tabular}

Table 6. Mean Carcass composition of L. rohita fry fed on different diets for 60 days ( $\%$ fresh matter basis)

\begin{tabular}{lllll}
\hline Components & $\begin{array}{l}\text { Initial } \\
\text { value }\end{array}$ & $\mathbf{D}_{\mathbf{1}}$ & $\mathbf{D}_{\mathbf{2}}$ & $\mathbf{D}_{\mathbf{3}}$ \\
\cline { 3 - 5 } & 77.09 & $75.84^{\mathrm{a}} \pm 0.76$ & $74.87^{\mathrm{b}} \pm 0.26$ & $74.26^{\mathrm{b}} \pm 0.10$ \\
Moisture & 11.79 & $14.33^{\mathrm{c}} \pm 0.32$ & $15.13^{\mathrm{b}} \pm 0.27$ & $16.39^{\mathrm{a}} \pm 0.11$ \\
Crude protein & 2.32 & $3.80^{\mathrm{b}} \pm 0.42$ & $4.16^{\mathrm{ab}} \pm 0.15$ & $4.56^{\mathrm{a}} \pm 0.20$ \\
Crude lipid & 4.66 & $2.23^{\mathrm{a}} \pm 0.21$ & $1.95^{\mathrm{ab}} \pm 0.13$ & $1.70^{\mathrm{b} \pm 0.18}$ \\
Ash &
\end{tabular}

*Values having the same subscripts in the same row are not significantly different $(\mathrm{P}>0.05)$ 


\section{Conclusions}

The result of the present study indicates that mustard oilcakes gave lower growth and poorer food conversion ratio compared to soybean based diets. The use of soybean meal (up to $50 \%$ ) might be advantageous for rearing of carp fingerlings.

\section{Acknowledgement}

The authors gratefully acknowledge BAUUSDA Soybean Project, for financial assistance to conduct this experiment.

\section{References}

AOAC, 1990. Official Methods of Analysis, $15^{\text {th }}$ edn. Association of Official Analytical Chemists, Washington, DC, USA, 1134, p.

APHA, 1990. Standard Methods for the examination of water and waste water. American Public Health Association, New York, 1193p.

Bellinger, E.G. 1992. A key to common algae: Freshwater estuarine and some coastal species. The Institute of Water and Environmental Management, London, UK, $138 \mathrm{p}$.

Devi, C., Vijayaraghavan, S. and Srinvasulu, C. 1999. Effect of soybean meal (Glycine max) feeding on the bio-chemical composition of Labeo rohita fingerlings. Journal of Aquaculture Tropics, 14(2): 181-185.

Duncun, D.B. 1955. Multiple range and multiple F-tests. Biometrics, 11:1-42.

El-Sayed, A.F.M. 1999. Alternative dietary protein sources for farmed tilapia, Oreochromis spp. Aquaculture, 179(14): $149-168$.

Hepher, B., 1988. Nutrition of pond Fishes. Cambridge University Press, Cambridge, New York, New Rochelle, Melboume, Sydney.

Hossain, M.A. and Jauncey, K. 1989. Nutritional evaluation of some Bangladeshi oilseed meals as partial substitutes for fish meal in the diet of common carp, Cyprinus carpio
L. Aquaculture Fish Management, 20: 255-268.

Jena, J.K., Mukhopadhyay, P.K. and Aravindakshan, P.K. 1999. Evaluation of a formulated diet for raising carp fingerlings in field condition. Journal of Applied Ichthyology, 15: 188-192.

Jhingran,V.G. and Pullin, R.S.V. 1985. A hatchery manual for the common, Chinese and Indian major carps. ICLARM Studies and Reviews 11. Asian Development Bank, Manila, Philippines and ICLARM, Manila, Philippines. 191 p.

Latif, K.A., Alam, M.T., Sayeed, M. A., Afzal Hossain, M., Sultana, S. and Hassina, M.A. 2008. Comparative study on the effect of low cost oil seed cakes and fish meal as dietary protein sources for Labeo rohita (Hamilton) fingerling. Univ. J. Zool. Rajshahi Univ., 27: 25-30.

Lim, C and Dominy, W. 1990. Evaluation of soybean meal as a replacement for marine animal protein in diets for Shrimp (Penaeus vannamei). Aquaculture, 87: 5364.

Priyadarshini, M., Manissery, J.K., Gangadhara, B., Rao, L.M. and Keshavanath, P. 2011. Growth responses of Catla catla (Actinopterygh:Cypriniformes:Cyprinidae ) to soya and maize supplemented traditional feed mixture. Acta Ichthyologica Et Piscatoria, 41(3) :159164.

Singh, P.K., Gaur, S.R., Barik, P., Sulochana, Smriti, S. and Singh, S. 2005. Effect of protein levels on growth and digestibility in the Indian major carp, Labeo rohita (Hamilton) using staughter house waste as a protein sources. International Journal of Agriculture \& Biology, 7(6):939-9941.

Singh, R. and Dhawan, A. 1996. Effects of formulated diets on the growth and ovarian maturation in common carp Cyprinus carpio Commnunis Linn. Indian Journal of Fisheries, 43 (4): 349-353.

Wilson, R.P. 1989. Amino acid and Proteins, In: Halver, J.E.(ed.), Fish Nutrition, $2^{\text {nd }}$ Ed. Academic Press, USA pp. 111-151. 